\title{
Kecemasan Pada Atlet Cabang Olahraga Bela Diri (Nomor Tarung)
}

\section{Anxiety in Martial Arts Athletes (Fighting Categories)}

\author{
Ajeng Dian Purnamasari ${ }^{1}$, Ayu Rizky Febriani ${ }^{2}$, Kusnandar ${ }^{3}$ \\ 1,2,3 Jurusan Pendidikan Jasmani, Fakultas IImu-IImu Kesehatan, Universitas Jenderal Soedirman. \\ Banyumas, Indonesia \\ email: ajeng.dian.purnama@unsoed.ac.id¹ \\ doi): https://doi.org/10.20884/1.paju.2020.2.1.3082
}

\begin{abstract}
Abstrak
Gangguan kecemasan menjadi salah satu gangguan yang sering muncul pada perjalanan performa atlet mecapai prestasi. kecemasan ini merupakan gangguan yang terjadi selalu dengan latar belakang atau pemicu. Untuk dapat menghindari kecemasan ini dapat mempelajari berbagai pemicu dari terjadinya kecemasan ini secara spesifik berdasarkan pada setiap cabang olahraga. Tujuan dari penelitian ini adalah untuk mengetahui berbagai kemungkinan pemicu kecemasan pada atlet bela diri (nomor tarung) di Kabupaten Banyumas baik atlet laki-laki maupun atlet perempuan. penelitian ini bersubjekkan atlet bela diri yang berdomisili di Kabupaten Banyumas sebanyak 163 atlet bela diri dari cabang olahraga Pencak Silat, Taekwondo dan Karate, dengan pengalaman bertanding minimal pada kejuaraan tingkat daerah. Penelitian ini menggunakan metode deskriptif analisis dengan pendekatan naturalistik dalam proses pengambilan data. Data diperoleh dengan penyebaran kuisioner serta melakukan pengecekan pernyataan dengan wawancara mendalam. Penganalisisan data dilakukan dengan menghitung presentase dari seluruh data yang saling mendukung dan mereduksi data yang tidak memberikan informasi. Hasil dari penelitian ini adalah informasi tentang penyebab paling dominan munculnya kecemasan yang biasanya terjadi pada atlet bela diri pada atlet Banyumas dari masing-masing kecabangan tersebut. Simpulan yang didapat dari penelitian ini kecemasan paling dominan adalah 1) Terdapat 9 pemicu kecemasan pada atlet laki-laki cabang olahraga beladiri nomor tarung, dengan pemicu paling dominan adalah pikiran tentang ingin segera bertanding dan Beban pikiran tentang strategi mengalahkan. 2) Terdapat 8 pemicu kecemasan pada atlet perempuan cabang olahraga beladiri nomor tarung, dan yang paling dominan adalah ketakutan akan kekalahan. 3) Pada atlet laki-laki pemicu kecemasan yang paling mendominasii adalah bentuk agresifitas dan pada perempuan lebih memunculkan sisi perasaan sensitif.
\end{abstract}

Kata Kunci : Pemicu Kecemasan, Atlet Bela Diri, Beladiri Nomor Tarung

\section{Abstract}

Anxiety disorder is one of the disorders that often appears in the way the athlete's performance reaches achievement. To be able to avoid this anxiety, we can study the various triggers of this anxiety specifically based on each sport.

Alamat Koresponden : Jurusan Pendidikan Jasmani, Fikes Universitas Jenderal Soedirman, Indonesia

Email : ajeng.dian.purnama@unsoed.ac.id

(c) (7)

Jurnal Physical Activity Journal (PAJU) This work is licensed under a Creative Commons Attribution 4.0 International License. 
This anxiety is a disorder that occurs always with a background or a trigger. The purpose of this study was to determine the various possible causes of anxiety in martial arts athletes (fighting categories) in the Banyumas Regency, both male athletes, and female athletes. This research is subjected to 163 martial athletes domiciled in Banyumas Regency, from the sports of Pencak Silat, Taekwondo and Karate, with minimal experience competing at regional level championships. This study uses a descriptive analysis method with a naturalistic approach in the data collection process. Data obtained by distributing questionnaires and checking statements through in-depth interviews. Data analysis is done by calculating the percentage of all data that support each other and reduce data that does not provide information. The results of this study are information about the most dominant cause of anxiety that usually occurs in martial arts athletes in Banyumas athletes. The conclusion from this study is that the most dominant anxiety is 1) There are 9 anxiety triggers in male athletes in combat numbers, with the most dominant triggers being thoughts about wanting to compete hurriedly and thoughts about beating strategies. 2) There are 8 triggers for anxiety in female athletes in combat numbers, and the most dominant one is the fear of defeat. 3) In male athletes, the most dominant trigger for anxiety is the form of aggressiveness and in women, the sensitive feelings are more prominent.

Keywords : Anxiety Trigger, Martial Athlete, the combat number Martial Arts

\section{PENDAHULUAN}

Keberhasilan atau kegagalan dalam melakukan sebuah teknik menyerang atau bertahan oleh atlet dalam sebuah pertandingan, bisa terjadi akibat banyak faktor. Secara garis besar faktor ini tentu berupa kondisi fisik atau psikis dari seorang atlet. faktor pertama yaitu kondisi fisik yang sudah sangat dikenal sebagai dasar yang perlu dilatih dalam meningkatkan dan memperkuat kemampuan tubuh dalam menguasai suatu teknik cabang olahraga apapun. Meski tidak semua faktor konsisi fisik harus menjadi dominan, karena dalam suatu keterampilan biasanya hanya terdiri dari beberapa kolaborasi dari faktor kondisi fisik tersebut.

Faktor kedua, untuk menyempurnakan kemampuan dari seseorang dalam memperkuat dirinya menguasai berbagai keterampilan terdapat yang juga mendukung yaitu faktor psikis. faktor psikis tampak lebih abstrak untuk dilihat namun sangat dirasakan oleh setiap individu. Hal ini juga didukung karena konsep diri yang mengungkapkan bahwa setiap individu itu unik dan tidak bisa disamakan satu dengan lain, hanya dapat dibandingkan pada situasi tertentu dalam menyikapi suatu intervensi pada dirinya. Faktor psikis sendiri dapat muncul dengan gejala yang berbeda pada diri masing-masing individu. 
Ajeng Dian Purnamasari, Ayu Rizky Febriani, Kusnandar | Kecemasan Pada Atlet Cabang Olahraga Bela Diri (Nomor Tarung)

Hal ini membutuhkan kajian yang cukup mendalam bagi setiap individu (dalam hal ini atlet), karena sangat memungkinkan kondisi atlet yang terlatih akan berbeda menyikapi suatu gangguan yang biasa dan tidak biasa dirasakan. Sama seperti kondisi fisik tentu hal ini harus dilatih.

Teori mengungkapkan tentang faktor psikologis juga butuh untuk dilatih sendiri, dengan program tersendiri (Nossek, 1995), sehingga jika merujuk pada bagaimana kemampuan fisik pada atlet dilatih dengan program yang terukur psikis juga memerlukan hal yang sama. Hal ini disampaikan juga oleh Rushall (2008) dan Kamnuron, Hidayat, \& Nuryadi (2020) merujuk pada mental yang terlatih untuk suatu olahraga dapat mengarahkan atlet pada peningkatan performanya. Maka, hendaknya faktor psikis juga wajib dilatih untuk mendapatkan hasil yang baik. Namun, untuk dapat memberikan program latihan akan butuh banyak pengkajian yang sesuai dengan kebutuhan dari kondisi psikis atlet yang ditangani. Selain itu menjadi sangat penting untuk mengetahui posisi kondisi psikis dari atlet. Setiap atlet dapat mengalami berbagai gangguan-gangguan yang berbeda sesuai dengan waktu dan gangguan psikis yang datang.

Salah satu gangguan mental yang dapat muncul adalah kecemasan. Studi pendahuluan menyatakan dari 10 atlet seluruhnya pernah mengalami gangguan kecemasan ini dan merasa mengganggu performa untuk meraih prestasi, sehingga menjadi sebuah fenomena bahwa cemas terjadi pada setiap individu atlet. Gangguan kecemasan ini memiliki dampak negatif yang sangat mengganggu pada suasana hati, memunculkan ketakutan, kesedihan, kemarahan dan memunculkan kesalahan (Wenar \& Kerig, 2000). Secara berurutan pada tubuh ketika muncul perasaan kecemasan ini memunculkan emosi-emosi negatif yang selanjutnya berdampak pada sistem kardiovaskular, gemetar serta kerja jantung terpacu lebih cepat/menuju keadaan hipertensi (Benson, H. dan Klipper, 2000). Sehingga jika dihubungkan dengan olahraga kondisi seperti ini tidak akan memaksimalkan atlet dalam mendapatkan performa terbaiknya.

Penelitian ini mencoba menggali berbagai informasi valid saat terjadinya kecemasan pada atlet dan penyebab munculnya kecemasan tersebut. fokus peneltian yaitu kecemasan yang terjadi pada atlet bela diri dengan cabang bela diri yang terlibat adalah Pencak silat, Tae Kwon Do dan Karate yang merupakan kecabangan dengan terdapat nomor tarung atau terdapat body contact (bersentuhan) antar pemain untuk bisa mendapatkan nilai. Karakteristik yang ada pada kecabangan Karate adalah adanya 
ancaman yang muncul dari lawan sehingga seorang atlet hanya memiliki pilihan antara bertahan dari serangan atau menyerang.

\section{METODE}

Penelitian ini menggunakan metode penelitian deskripsi analisis, dengan pendekatan naturalistik. Metode ini memungkinkan mendeskripsikan data dengan memberi gambaran terhadap suatu objek sebagaimana adanya, dan membuat kesimpulan secara umum (Sugiyono, 2016). Data didapatkan dengan survei tertutup dengan alat pengumpulan data kuisioner yang disebarkan kepada 163 atlet yaitu 50 Pencak silat, 55 atlet Tae Kwon Do dan 53 atlet Karate, dengan pembatasan atau kriteria inklusi adalah atlet Karate yang bersedia memberi informasi, pernah bertanding minimal pada tingkat daerah tingkat II dan memiliki domisili atau berlatih di wilayah Banyumas, Jawa Tengah. Pengambilan data dilakukan dengan tertutup untuk menghindari penggunaan data yang tidak sesuai kebutuhan.

Butir pertanyaan yang diberikan pada yang digunakan sebagai alat pengumpulan data terdiri dari 5 poin pertanyaan merujuk pada kisi-kisi pertanyaan yang yang digunakan oleh (Purnamasari, Kusnandar, \& Febriani, 2019) yaitu:

1. Pernahkah merasakan kecemasan pada tahap latihan sampai tahap berakhirnya masa pertandingan?

2. Kapan anda merasakan kecemasan tersebut muncul?

3. Tuliskan/jabarkan yang menjadi penyebabkan kecemasan yang anda rasakan!

4. Pernahkah anda merasakan ketakutan melakukan kesalahan pada teknik dasar yang harusnya anda kuasai dalam cabang olahraga anda?

5. Teknik apa yang paling anda khawatirkan akan salah jika anda lakukan?

Pertanyaan diatas digunakan oleh peneliti untuk mendapatkan data utama, yang didukung dengan wawancara mendalam untuk menentukan tingkat validitas pada data yang dianggap belum valid. Selanjutnya diadakan proses analisis data, proses ini dilakukan dengan menjumlahkan pernyataan yang sama dan mereduksi data yang tidak mendukung informasi dan menghitung jumlah serta persentase dari setiap data yang didapat . Data yang didapat disajikan dalam bentuk akumulasi pernyataan sebagai hasil dari penelitian. 
Ajeng Dian Purnamasari, Ayu Rizky Febriani, Kusnandar | Kecemasan Pada Atlet Cabang Olahraga Bela Diri (Nomor Tarung)

\section{HASIL}

Setelah melakukan pengkatagorian didapatkan data yang terdiri dari 6 (enam) katagori sesuai dengan jenis kelamin dan kecabangan olahraganya yaitu sebagai berikut:

1. Penyebab kecemasan pada atlet Laki-laki Cabor Pencak Silat

Informan atlet Pencak Silat laki-laki yang berjumlah 20 atlet telah membagikan informasi dan didapatkan data yang sering menjadi pemicu atau penyebab terjadinya kecemasan yaitu:

Tabel 1. Penyebab Kecemasan pada Atlet Laki-laki Cabor Pencak Silat

\begin{tabular}{clc}
\hline No & \multicolumn{1}{c}{ Bentuk Pemicu kecemasan } & Banyaknya Pernyataan \\
\hline 1 & Pikiran ingin segera bertanding & 8 \\
\hline 2 & Beban menyusun strategi mengalahkan & 10 \\
\hline 3 & Menunggu jadwal pertandingan & 1 \\
\hline 4 & Belum mengetahui teknik/kemampuan lawan & 1 \\
\hline Jumlah & $\mathbf{2 0}$
\end{tabular}

Data pada tabel 1 menunjukkan pemicu kecemasan pada atlet pencak silat berjenis kelamin laki-laki, setelah pentabulasian atau mengumpulkan seluruh pernyataan didapatkan 8 atlet mengatakan pikiran ingin segera bertanding, 10 atlet menyatakan beban pikiran tentang strategi mengalahkan (lawan dipertandingan), 1 atlet menunggu jadwal pertandingan dan 1 atlet mengatakan cemas jika belum mengetahui teknik/atau kemampuan lawan. Sehingga, didapatkan dari 20 atlet yang memberikan informasi didapatkan dominasi kecemasan terjadi dengan dua alasan yaitu akibat pikiran dari atlet yang ingin segera bertanding dan beban menyusun strategi mengalahkan.

2. Pemicu kecemasan pada atlet Pencak Silat perempuan

Informan yang merupakan atlet Pencak Silat perempuan yang berjumlah 30 atlet telah membagikan informasi yang didapatkan data yang sering menjadi pemicu atau penyebab terjadinya kecemasan yaitu:

Tabel 2. Data Pemicu Kecemasan pada Atlet Perempuan Cabor Pencak Silat

\begin{tabular}{clc}
\hline No & \multicolumn{1}{c}{ Bentuk Pemicu kecemasan } & Banyaknya Pernyataan \\
\hline 1 & Melihat lawan sebelum bertanding & 1 \\
\hline 2 & Pikiran ingin segera bertanding & 7 \\
\hline
\end{tabular}




\begin{tabular}{clc}
\hline 3 & Semakin mendekatnya waktu pertandingan & 8 \\
\hline 4 & Memikirkan tentang kekalahan & 12 \\
\hline 5 & Ketakutan akan kesalahan teknik sendiri & 1 \\
\hline 6 & Pikiran tentang cedera & 1 \\
\hline Jumlah & 30 \\
\hline
\end{tabular}

Tabel 2 merupakan hasil tabulasi dan analisis pernyataan-pernyataan dari informan (atlet) pada cabang Pencak Silat dengan jenis kelamin perempuan. Pernyataan 12 atlet kecemasan terpicu oleh pikiran tentang kekalahan, kemudian dua alasan lain yaitu semakin mendekatnya waktu pertandingan dan pikiran segera ingin bertanding diungkapkan oleh masing-masing 7 dan 8 orang atlet. Sedangkan alasan melihat lawan sebelum bertanding, ketakutan akan melakukan kesalahan teknik dan pikiran tentang cedera, masing-masing diungkapkan oleh 1 atlet. Sehingga didapat alasan yang paling banyak menentukan muncunya kecemasan adalah pikiran tentang kekalahan.

3. Pemicu kecemasan pada atlet Taekwondo laki-laki

Data ini merupakan data dari atlet cabang olahraga Taekwondo, salah satu cabang olahraga beladiri yang populer dan dipertandingkan pada tingkat kecamatan sampai nasional. Penggalian pada atlet laki-laki cabang olahraga ini mendapatkan data pemicu kecemasan yang paling sering muncul adalah tertera pada tabel 3 :

Tabel 3. Pemicu kecemasan pada atlet Taekwondo laki-laki.

\begin{tabular}{clc}
\hline No & \multicolumn{1}{c}{ Bentuk Pemicu kecemasan } & Banyaknya Pernyataan \\
\hline 1 & Ketakutan akan kekalahan & 3 \\
\hline 2 & Takut akan catatan lawan yang lebih baik & 4 \\
\hline 3 & Ketakutan akan beban latihan yang berat & 1 \\
\hline 4 & Tidak yakin bisa menang (tidak percaya diri) & 5 \\
\hline 5 & Panik tanpa sebab & 3 \\
\hline 6 & Ketakutan tidak dalam berforma terbaik & 1 \\
\hline 7 & lawan lebih tinggi & 2 \\
\hline 8 & Ketakutan salah melakukan teknik dasar & 7 \\
\hline 9 & Merasa kurang latihan & 1 \\
\hline 10 & Takut mengecewakan orang lain & 27 \\
\hline Jumlah &
\end{tabular}


Ajeng Dian Purnamasari, Ayu Rizky Febriani, Kusnandar | Kecemasan Pada Atlet Cabang Olahraga Bela Diri (Nomor Tarung)

Data pada tabel 3 menggambarkan angka yang menyatakan menyatakan angka pemicu kecemasan tertinggi bagi atlet laki-laki cabang olahraga taekwondo sebanyak 7 pernyataan yaitu atlet merasa kurang latihan, dengan 5 pernyataan atlet pemicu kecemasan tersebut adalah tidak yakin bisa menang (tidak percaya diri). 4 (empat) atlet menyatakan takut jika lawan tercatat lebih kuat dari pada dirinya, masing-masing 3 atlet menyatakan ketakutan akan kekalahan dan panik tanpa sebab. Terakhir masingmasing 1 atlet menyatakan cemas diakibatkan oleh ketakutan akan beban latihan yang berat sehingga terdapat 27 pernyataan.

4. Pemicu kecemasan pada atlet Taekwondo Perempuan

Data selanjutnya adalah data kecemasan pada atlet perempuan cabang olahraga taekwondo yaitu pada tabel 4 :

Tabel 4. Data Pemicu kemasan pada atlet perempuan Cabor Taekwondo

\begin{tabular}{clc}
\hline No & \multicolumn{1}{c}{ Bentuk Pemicu kecemasan } & Banyaknya Pernyataan \\
\hline 1 & Ketakutan akan kekalahan & 18 \\
\hline 2 & Takut akan catatan lawan yang lebih baik & 3 \\
\hline 3 & Ketakutan akan beban latihan yang berat & 1 \\
\hline 4 & Suasana tempat bertanding yang ramai/ terpengaruh & 2 \\
& situasi di gelanggang & 1 \\
\hline 5 & Takut lupa teknik saat bertanding & 1 \\
\hline 6 & Tidak yakin bisa menang (tidak percaya diri) & 1 \\
\hline 7 & Panik & 1 \\
\hline 8 & Ketakutan tidak dalam berforma terbaik & 1 \\
\hline Jumlah & lawan lebih tinggi & 28
\end{tabular}

Dapat dijabarkan dari data di atas dapat dilihat 18 atlet menyatakan bahwa ketakutan akan kekalahan menjadi yang mendominasi dalam memicu kecemasan, selanjutnya takut akan catatan lawan yang dikatakan lebih baik dikatakan 3 atlet sebagai pemicu kecemasan. Pemicu kecemasan dengan pernyataan dari 2 atlet yaitu suasana tempat bertanding yang ramai, sedangkan masing-masing dinyatakan oleh 1 orang atlet adalah ketakutan akan beban latihan yang berat, takut lupa teknik saat bertanding, tidak yakin bisa menang (tidak percaya diri), panik, ketakutan tidak dalam perfrma terbaik dan jika lawan lebih tinggi. 
5. Penyebab kecemasan pada atlet Laki-laki Cabor Karate

Berikut adalah data yang diperoleh dari 25 atlet laki-laki cabang olahraga Karate, tertera pada tabel di bawah ini:

Tabel 5. Penyebab kecemasan pada atlet Laki-laki Cabang Olahraga Karate.

\begin{tabular}{clc}
\hline No & \multicolumn{1}{c}{ Bentuk Pemicu kecemasan } & Banyaknya Penyataan \\
\hline 1 & Takut akan cedera & 1 \\
\hline 2 & Tidak yakin bisa menang (tidak percaya diri) & 2 \\
\hline 3 & Takut akan memilih teknik yang salah & 1 \\
\hline 4 & Terpengaruh suasana di gelanggang (ramai) & 3 \\
\hline 5 & Takut akan catatan lawan yang lebih baik & 1 \\
\hline 6 & Ketakutan akan kurangnya kontrol diri dalam & 3 \\
\hline 7 & pertandingan (membuat pelanggaran) & \\
\hline 8 & Takut menghadapi lawan yang belum pernah bertemu & 4 \\
\hline 9 & Takut akan kekalahan & 25
\end{tabular}

Angka pada data di atas menyatakan pemicu kecemasan pada atlet laki-laki cabang olahraga Karate. Data terbanyak yaitu 7 atlet menyatakan cemas disebabkan oleh terpengaruh pada suasana gelanggang. 4 orang atlet menyatakan takut akan kekalahan, masing-masing 3 atlet menyatakan takut akan catatan lawan yang lebih baik, takut menghadapi lawan yang belum pernah bertemu sebelumnya, takut saat mengawali pertandingan. 2 atlet menyatakan tidak yakin bisa menang (tidak percaya diri), dan lainnya masing-masing 1 atlet menyatakan takut akan cedera, takut akan memilih teknik yang salah dan ketakutan akan kurangnya kontrol diri dalam bertanding yang mengakibatkan melakukan pelanggaran.

6. Pemicu kecemasan pada atlet perempuan Cabang Olahraga Karate

Berikut adalah data ke-6 yang ada didapatkan pada penelitian ini yaitu data pemicu kecemasan dari atlet perempuan yang tarung pada cabang olahraga Karate:

Tabel 6. Data Pemicu kecemasan pada atlet perempuan Cabang Olahraga Karate.

\begin{tabular}{clc}
\hline No & \multicolumn{1}{c}{ Bentuk Pemicu kecemasan } & Perempuan \\
\hline 1 & Takut akan cedera & 2 \\
\hline 2 & Tidak yakin bisa menang (tidak percaya diri) & 4
\end{tabular}


Ajeng Dian Purnamasari, Ayu Rizky Febriani, Kusnandar | Kecemasan Pada Atlet Cabang Olahraga Bela Diri (Nomor Tarung)

\begin{tabular}{clc}
\hline 3 & Takut akan memilih teknik menyerang & 1 \\
\hline 4 & Terpengaruh suasana di gelanggang & 5 \\
\hline 5 & Takut akan catatan lawan yang lebih baik & 7 \\
\hline 6 & $\begin{array}{l}\text { Ketakutan akan kurangnya kontrol diri dalam pertandingan } \\
\text { (membuat pelanggaran) }\end{array}$ & 1 \\
\hline 7 & Takut akan kekalahan & 8 \\
\hline Jumlah & 28
\end{tabular}

Tabel di atas menyatakan banyaknya atlet perempuan pada cabang olahraga Karate yang cemas diakibatkan oleh takut akan kekalahan sebanyak 8 atlet. Takut akan catatan lawan yang lebih baik dinyatakan oleh 7 atlet. 5 atlet menyatakan cemasnya dipicu oleh terpengaruhnya suasana di gelanggang, 4 atlet menyatakan ketidak percayaan diri yang kemudian berfikir bahwa dirinya tidak yakin menang. 2 atlet menyatakan takut akan cedera dan terakhir masing-masing 1 atlet mengatakan takut akan memilih teknik menyerang serta ketakutan akan kurangnya kontrol diri dalam pertandingan yang membuat dirinya melakukan pelanggaran.

\section{PEMBAHASAN}

\section{Kecemasan Atlet Bela Diri Laki-Laki Nomor Tarung}

Data pemicu kecemasan pada atlet laki-laki jika diakomodir menjadi satu dari interpretasi data sebelumnya, yang paling dominan muncul adalah sebagai berikut:

Tabel 7. Data pemicu kecemasan pada atlet Laki-laki yang paling dominan.

\begin{tabular}{clllll}
\hline No & Bentuk Pemicu kecemasan & Pencak Silat & Taekwondo & karate & Jumlah \\
\hline 1 & Pikiran ingin segera bertanding & 10 & - & - & 10 \\
\hline 2 & $\begin{array}{l}\text { Memikirkan/takut tentang } \\
\text { kekalahan }\end{array}$ & - & 3 & 4 & 7 \\
\hline 3 & $\begin{array}{l}\text { Ketakutan akan kesalahan teknik } \\
\text { sendiri }\end{array}$ & - & 2 & 2 & 4 \\
\hline 4 & $\begin{array}{l}\text { Beban pikiran tentang Strategi } \\
\text { Mengalahkan }\end{array}$ & 10 & - & - & 10 \\
\hline 5 & $\begin{array}{l}\text { Belum mengetahui } \\
\text { teknik/kemampuan lawan }\end{array}$ & 2 & & 3 & 5 \\
\hline 6 & $\begin{array}{l}\text { Takut akan catatan lawan yang } \\
\text { lebih baik }\end{array}$ & - & 4 & 3 & \\
\hline
\end{tabular}




\begin{tabular}{clllll}
\hline 7 & Tidak yakin bisa menang (tidak & - & 5 & 2 & 7 \\
& percaya diri) & & & \\
\hline 8 & $\begin{array}{l}\text { Terpengaruh suasana di } \\
\text { gelanggang }\end{array}$ & - & - & 7 & 7 \\
\hline 9 & Merasa kurang latihan & - & 7 & - & 7 \\
\hline
\end{tabular}

Gambaran pada dominasi pernyataan tentang apa saja pemicu kecemasan yang terjadi pada atlet laki-laki cabang olahraga beladiri nomor tarung. Dapat dilihat dari 9 pernyataan yang mendominasi keseluruhnya terdapat 2 yang paling mendominasi yaitu pikiran tentang ingin segera bertanding dan Beban pikiran tentang Strategi Mengalahkan yang keduanya dinyatakan oleh masing-masing 10 atlet atau keduanya menunjukkan persentase $27,78 \%$ dari seluruh pernyataan yang ada. Pikiran ingin segera bertanding dan memikirkan strategi untuk mengalahkan lawan, menggambarkan bahwa pada atlet laki-laki ingin segera menyelesaikan sebuah intervensi keinginan pada dirinya yang sejalan dengan sikap agresif yang muncul, akibat dari tipe maskulin pada laki-laki (Dwiyono, 2009). Namun, jika dikaji kembali terdapat kesenjangan antara pernyataan pada atlet cabang olahraga Pencak Silat, Taekwondo dan Karate, dan ini membutuhkan penelitian lebih dalam penyebab dari kesenjangan tersebut.

Selain dua pernyataan sebelumnya, masih terdapat 4 pernyataan lain yang menunjukkan sikap logis dan objektif dari laki-laki, yaitu ketakutan akan salah teknik, belum mengetahui kemampuan lawan, takut akan catatan lawan yang lebih baik, merasa kurang latihan. Keempat hal tersebut adalah beberapa hal yang menjadi pertimbangan untuk menyusun strategi untuk menang, bahwa konsep dalam suatu pertandingan adalah yang terkuat, tertinggi atau tercepatlah yang dapat memenangkan kompetisi. Jika memahami kekuatan lawan, maka seorang atlet beladiri akan dapat ditentukan latihan apa yang cocok untuk bisa melawan keunggulaan lawan. Dan dalam menjalani pertandingan akan ada kemungkinan kesalahan atlet melakukan kesalahan pemilihan teknik atau kelalaian teknik yang bisa saja disebabkan oleh pengaruh suasana tempat bertandingan yang juga menjadi salah satu alasan yang diungkapkan (pada tabel 7 poin ke-8). Pemikiran logis dan objektif ini sesuai dengan bagaimana perspektif laki-laki yang disampaikan oleh Broverman (1972) bahwa laki-laki memiliki kepribadian yang logis, objektif dan mengetahui jalannya untuk mencapai tujuan. 
Ajeng Dian Purnamasari, Ayu Rizky Febriani, Kusnandar | Kecemasan Pada Atlet Cabang Olahraga Bela Diri (Nomor Tarung)

\section{Kecemasan Atlet Bela Diri Perempuan Nomor Tarung}

Data pemicu kecemasan pada atlet perempuan berdasarkan pernyataan yang analisis dengan mereduksi angka-angka pernyataan terendah seperti ditunjukkan pada tabel berikut:

Tabel 8. Data Pemicu Kecemasan Pada Atlet Perempuan Yang Paling Dominan.

\begin{tabular}{|c|c|c|c|c|c|}
\hline No & Bentuk Pemicu kecemasan & $\begin{array}{c}\text { Pencak } \\
\text { silat }\end{array}$ & $\begin{array}{c}\text { Tae kwon } \\
\text { do }\end{array}$ & Karate & Jumlah \\
\hline 1 & Pikiran ingin segera bertanding & 7 & - & - & 7 \\
\hline 2 & Semakin mendekatnya pertandingan & 8 & - & - & 8 \\
\hline 3 & Memikirkan/takut tentang kekalahan & 12 & 18 & 8 & 38 \\
\hline 4 & Ketakutan akan kesalahan teknik & 1 & 1 & 2 & 4 \\
\hline 5 & Pikiran tentang cedera & 1 & & 2 & 3 \\
\hline 6 & $\begin{array}{l}\text { Takut akan catatan lawan yang lebih } \\
\text { baik }\end{array}$ & - & 3 & 7 & 10 \\
\hline 7 & $\begin{array}{l}\text { Suasana tempat bertanding yang } \\
\text { ramai/ terpengaruh situasi di } \\
\text { gelanggang }\end{array}$ & - & 2 & 5 & 7 \\
\hline 8 & $\begin{array}{l}\text { Tidak yakin bisa menang (tidak } \\
\text { percaya diri) }\end{array}$ & - & 1 & 4 & 5 \\
\hline
\end{tabular}

Berdasarkan data pada tabel 7, yang merupakan urutan pernyataan paling mendominasi dan paling banyak sebagai pernyataan atlet perempuan, dalam pemicu kecemasan menyatakan sepanjang mencapai prestasi pada cabang olahraga bela diri nomor tarung di Kabupaten Banyumas, Jawa Tengah. Urutan pertama adalah ketakutan akan kekalahan dengan banyaknya atlet yang menyatakan adalah 38 atlet atau sebanyak 44,19\%, diurutan kedua ketakutan akan catatan lawan dengan kemampuan yang lebih baik sebanyak 10 orang atlet atau sebanyak 11,63\%. Dan diurutan ketiga yaitu semakin mendekatnya waktu pertandingan dengan pernyataan 8 atlet atau $9,3 \%$.

Data tersebut menunjukkan bahwa kecemasan pada atlet perempuan paling dominan adalah tentang perasaannya sendiri yang memang sensitif terhadap rasa sakit atau kecewa, hal ini dapat didasari oleh keadaan wanita yang terbiasa bahwa kalah adalah hal yang dianggap lumrah atau biasa (segi negatif), bahkan dianggap selalu mengalah meski ini merupakan bias yang terjadi akan konsep yang beredar sejak lama, perempuan 
akan selalu kalah dibandingkan laki-laki, dan menjadi hal yang tertanam bahwa lebih mungkin untuk kalah dari pada menang atau tidak berprestasi (Nurhayati, 2012).

Dibandingkan dengan apa yang disampaikan Maccoby dan Jacklin (1974) sebenarnya perempuan yang dianggap tidak dapat berprestasi sangat memiliki kemungkinan untuk dapat prestasi jika tidak merasakan takut akan sukses (fear of succes), pernyataan ini jelas tersanggah oleh pernyataan para atlet yang secara gamblang pada urutan ke-8 bahwa dirinya tidak yakin untuk menang yang mereka alihkan sebagai ketidak percayaan pada dirinya sendiri. Sehingga jika secara teori pada diri seorang perempuan hendaknya tidak membiasakan untuk mengatakan sesuatu yang lemah atau tidak percaya diri jika dibekali dengan latihan yang cukup dan sudah sesuai dengan apa yang targetkan, sama seperti pada laki-laki kesempatan untuk menang tanpa diliputi rasa takut terlebih dahulu juga bisa mungkin didapatkan, karena pada dasarnya Maslow dalam Nurhayati (2012) Perempuan dapat mandiri, asertif dan sukses jika memiliki keyakinan kuat bahkan perempuan dan laki-laki sama-sama berusaha memenuhi kebutuhannya secara hirarkis.

Pembahasan ini menarik dikaitkan dengan perempuan dalam artian sebagai atlet. Jika dikembalikan pada kecemasan dan gangguan metabolisme yang ditimbulkan, menjadi sangat banyak masalah pangkal dan akibat yang merugikan. Setelah mengetahui kecemasan tersebut terjadi pada seseorang baik laki-laki maupun perempuan, apalagi terhadap mereka yang berstatus sebagai atlet, maka dibutuhkan penanganan serius terhadap kecemasan yang dihadapi seorang atlet.

Pada akhirnya gangguan psikis berupa kecemasan ini membutuhkan perhatian khusus yang dapat memberikan perubahan atas apa yang dirasakan (ketakutan dan kecemasan tersebut). Sehingga atlet perempuan mendapatkan puncak prestasi terbaik yang diharapkan. Lebih sederhana lagi tidak hanya pada perempuan yang menjadi atlet, bahwa dalam memberikan pembentukan kepribadian pada perempuan dasarnya adalah dapat membangun konsep yang tidak bias namun tetap memiliki batas sesuai dengan kemampuan dari tubuh perempuan tetapi bukan pemikiran yang mematok bahwa bias-bias tersebut adalah nyata pada diri seorang perempuan. Dibutuhkan konsep perempuan secara utuh untuk menjadi perempuan yang berkemampuan maksimal. 
Ajeng Dian Purnamasari, Ayu Rizky Febriani, Kusnandar | Kecemasan Pada Atlet Cabang Olahraga Bela Diri (Nomor Tarung)

\section{SIMPULAN}

Kesimpulan yang didapat dari berbagai pembahasan tersebut adalah terdapat 9 pemicu kecemasan pada atlet laki-laki cabang olahraga beladiri nomor tarung, dengan pemicu paling dominan adalah pikiran tentang ingin segera bertanding dan Beban pikiran tentang strategi mengalahkan. Terdapat 8 pemicu kecemasan pada atlet perempuan cabang olahraga beladiri nomor tarung, dan yang paling dominan adalah ketakutan akan kekalahan. Pada atlet laki-laki pemicu kecemasan yang paling mendominasii adalah bentuk agresifitas dan pada perempuan lebih memunculkan sisi perasaan sensitif.

Saran yang dapat diberikan dari hasil penelitian ini ditujukan untuk seluruh praktisi olahraga, bahwa setiap atlet yang menuju pencapaian prestasi memiliki permasalahan psikis yang berhubungan tentang kecemasan yang berbeda antara satu atlet dengan atlet yang lain. Pada atlet perempuan permasalahan lebih pada tindakan yang bermula dari perasaan dan pada laki-laki lebih pada logika untuk menang (agrasifitas). Dengan demikian sebagai modal awal dalam penggalian permasalahan kecemasan dapat bermula dari referensi ini.

\section{REFERENSI}

Benson, H. dan Klipper, M. Z. (2000). Bebas Stres dalam 10 Menit: Metode Respon Relaksasi. Bandung: Kaifa.

Broverman, IK. et. al. (1972). Sex-role Stereotypes and Clinical Judgments of Mental Health. Journal of Conseling and Clinical Psichology [34]:1-7.

Dwiyono, Frenky. (2009). Kecenderungan Berprilaku Agresif Ditinjau dari Identitas Peran Gender. Skripsi. Program Studi Psikologi Universitas Sanata Dharma.

Kamnuron, A., Hidayat, Y., \& Nuryadi, N. (2020). Perbedaan Kepercayaan Diri Pada Siswa yang Mengikuti Ekstrakurikuler Olahraga. Physical Activity Journal. https://doi.org/10.20884/1.paju.2020.1.2.2394

Maccoby, E. dan Jacklin, CN. (1974). The Psychology of Sex Defferences. Stanford Ca: Stanford University Press.

Nossek, Y. (1995). Teori Latihan Umum. Surakarta: UNS Pers.

Purnamasari, A. D., Kusnandar, K., \& Febriani, A. R. (2019). Bentuk Pemicu Kecemasan Atlet Pencak Silat. Jurnal Pendidikan Olahraga. 
https://doi.org/10.31571/jpo.v8i2.1109

Rushall, Brent. (2008). Mental Skill Training for Sport. San Diego State University and Sport Science Associates.

Septianingrumg, kartika. et. al (2018). Kontribusi Kondisi Fisik terhadap Performa Drag Flick. Jurnal Pendidikan: Teori, Penelitian dan Pengembangan, Vol. 3 No. 2 (513517).

Sugiyono, P. D. (2016). metode penelitian kuantitatif, kualitatif,dan R\&D. In Alfabeta, cV. Bandung: Alfabeta.

Wenar, C., \& Kerig, P. (2000). Developmental psychopathology: From infancy through adolescence. 